\title{
狭い間隙に進入する火炎の挙動に関する実験的研究*
}

\author{
小 原 哲 郎*1, 大八木 重 治*1

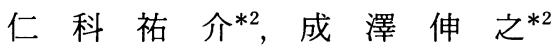

\section{Experimental Study on Behavior of a Flame Entering into a Narrow Channel}

\author{
Tetsuro OBARA*3, Shigeharu OHYAGI, \\ Yusuke NISHINA and Nobuyuki NARISAWA \\ ${ }^{* 3}$ Department of Mechanical Engineering, Saitama University, \\ 255 Shimo-Ohkubo, Sakura-ku, Saitama-shi, Saitama, 338-8570 Japan
}

\begin{abstract}
A behavior of a flame propagating through a narrow channel is of importance, since this phenomenon is concerned with a quenching of the flame when heat losses by convective heat transfer or radiative one to a wall of channel are dominant and temperature behind the flame is not enough to increase that of unburned gases. Since, this phenomenon is also related to a safety-engineering problem where combustible gaseous mixture is handled, a device applying a narrow channel in a pipe might be one of useful technique to prevent the flame from propagating. Experiments were conducted to investigate a behavior of the flame propagating through a narrow channel, which connects two rectangular combustion chambers. The behavior of the flame was visualized using schlieren optical technique with an aid of high-speed video camera. In this study, an equivalence ratio of methaneair mixture, initial pressure and a width of the channel were varied in order to investigate effects of these parameters on characteristics of the flame propagation. As a result, the behavior of the flame entering into the narrow channel was classified into two phenomena, i.e. ( $i$ ) the flame was quenched inside the narrow channel and combustion wave was not propagated into the downstream chamber, which results in just an emission of burned gaseous jet to the downstream chamber, (ii) the flame was propagated through the channel without quenching, which produced a high-pressure at both chambers.
\end{abstract}

Key Words : Combustion, Premixed Combustion, Combustion Phenomena, Pressure Wave, Flow Visualization

\section{1. は じめに}

可燃性予混合気体中を伝ぱする火炎が狭い間隙に 進入した際には, 物理的に興味深い現象が引き起こさ れる. まず，火炎は燃焼による熱量を火炎前方の未燃 気体に熱伝導で伝えながら伝ぱする機構である.した がって, 火炎が間隙に進入した際には, 既燃気体にお ける熱量の一部が対流熱伝達およびるく射熱伝達機構 によって間隙を構成する壁面へ伝達されるため, 未燃 気体へ移動する熱量は相対的に隇少する. したがって, 波面前方における予熱帯の温度が低下してその伝ぱ速 度は隇少し，間腙が十分長い場合には火炎は間隙内に おいて消炎すると考えられる(1). また，間隙内では流 れのレイノルズ数が小さく粘性の影響が顕著であるこ

* 原稿受付 2005 年 10 月 31 日.

*1 正員, 埼玉大学工学部(画338-8570さいたま市桜区下大久 保 255).

*2 埼玉大学大学院理工学研究科.

E-mail : tobara@ mech.saitama-u.ac.jp
とも, 火炎を消炎させる一要因である.

一方，閉鎖された空間において燃焼する場合には， 急速に膨張する既燃気体のピストン効果により火炎前 方には圧力波が生成され，燃焼室内で反射を絽返すこ とになる. 圧力波は未燃気体の音速で伝ぱすることか ら火炎の伝ぱ速度の $10^{2}$ 倍のオーダーである. した がって, 圧力波が間隙内を伝ぱすることにより未燃気 体の圧力は上昇するとともに末燃気体中に流れが誘起 され, 火炎の伝ぱ速度は速くなる. さらに, 間隙上流 の燃焼室では定容に近い燃焼状態になり圧力が上昇す るため, 間隙を伝ぱする火炎は既燃気体の高圧によっ て押される形態となる.したがって，燃焼過程におけ る圧力上昇の影響が顕著であれば, 間腙幅が火炎に対 して定義される消炎距離より小さい条件においても火 炎は消炎せずに間隙を伝ぱすると考えられる．すなわ ち，火炎が間隙に進入した際には，(i) 壁面への熱損 失および粘性の影響により消炎に至る場合と, (ii) 既 


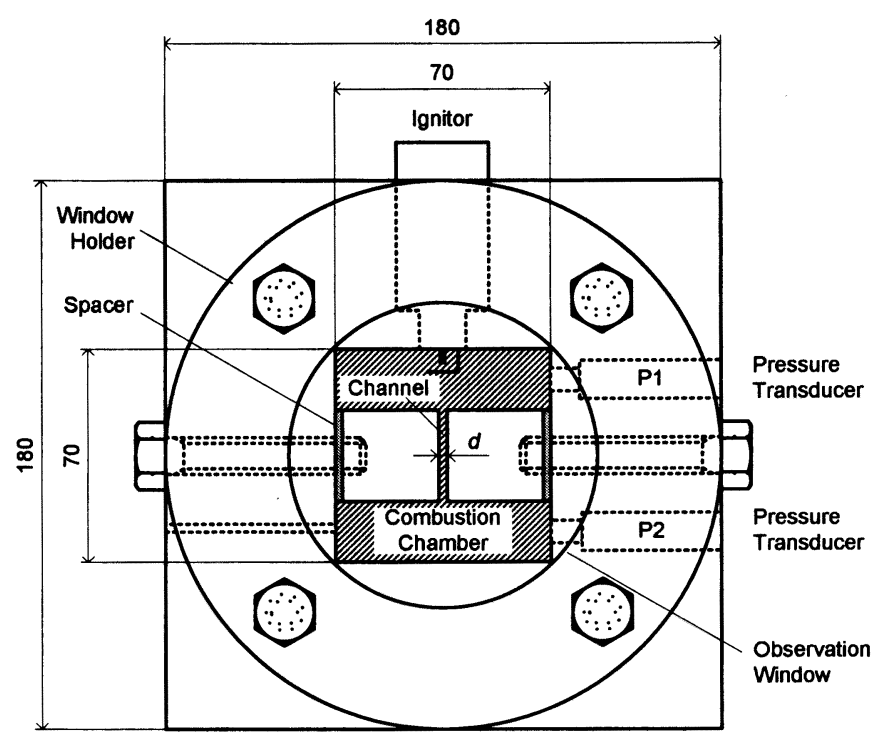

Fig. 1 Schematic diagram of combustion chamber $\left(70 \times 70 \times 40 \mathrm{~mm}^{3}\right)$. Chamber is divided into upper and lower section by a narrow channel $(d$ : width of channel).

燃気体の圧力上昇にともない火炎の伝ぱが促進される 二つの効果が考えられ，これら要因の卓越により火炎 の伝ぱ挙動は大きく異なると予想される.

これまでに, 壁面における境界条件を変化させ, 生 成される火炎の形状や伝ぱ速度と消炎距離の関係が数 值計算によって明らかにされている(2) (3). また, 消 炎距離を明らかにするための実験がフラッシュバック 法を用いて行われており ${ }^{(4)}{ }^{(5)}$, 比較的広い空間から 間隙に進入する際の火炎の消炎距離について確率論的 に求められている ${ }^{(5)}$. また, 消炎距離と最小点火エネ ルギーとの相関 ${ }^{(6)}$, 定容容器内で発生させた火炎が壁 面近傍において消炎する際の消炎距離が壁面材料を変 化させることにより実験的に求められており, 壁面へ の熱流束に対する消炎距離の関係が明らかにされてい る(7).これまでの研究では, 開放空間における火炎の 消炎現象に着目した研究は多くあるが, 現実には密閉 された空間を火炎が伝ぱする現象は多く存在する.し たがって定容燃焼室内において圧力上昇を伴った場合 の消炎現象について明らかにすることが重要と考えら れる.

本論では, 定容燃焼室の中央に間隙を設け, 間隙上 部において混合気体を点火した際に生成される火炎が 間隙を伝ぱする際の挙動についてシュリーレン光学系 および高速度ビデオカメラを用いて可視化観察した. また, 可視化観察と同時に燃焼室内の圧力計測を行っ た. 混合気体の当量比 $\phi$, 初期圧力 $p_{0}$, 間隙幅 $d$ を変
化させて実験を行い，火炎の伝ぱ挙動に及ぼす影響に ついて調べたので報告する.

\section{2. 実䄼装置および方法}

$2 \cdot 1$ 実伢装置図1に実験に用いた燃焼容器の概 略を示す. 燃焼容器は真ちゅう製であり, 幅 $180 \mathrm{~mm}$, 高さ $180 \mathrm{~mm}$, 奥行 $95 \mathrm{~mm}$ の大きさである. 燃焼容器 内部には, 幅 $70 \mathrm{~mm}$, 高さ $70 \mathrm{~mm}$, 奥行 $40 \mathrm{~mm}$ の燃 焼室が設けてある. すなわち, 一辺が $70 \mathrm{~mm}$ の正方 形にくり貫いた平板を光学ガラス (BK-7) が埋め込ん である二枚の板で両側から挟み, ボルトで締結するサ ンドイッチ構造である. 正方形にくり貫いた燃焼室内 に幅 $32 \mathrm{~mm}$, 高さ $30 \mathrm{~mm}$, 奥行 $40 \mathrm{~mm}$ の真ちゅう製 ブロックを燃焼容器の左右からボルトで固定すること により, 燃焼室中心軸上に間隙を設けた. 間隙幅 $d$ を 変化させるには, 燃焼容器と真ちゅう製ブロックとの 間にスペーサーを挿入した. この間隙により燃焼室は 上部と下部に分離されることになり, それぞれの燃焼 室を上室，下室と呼ぶことにする．実際に上室が鉛直 上方になるように実験室に設置されている. 上室およ び下室の容積はそれぞれ $5.32 \times 10^{4} \mathrm{~mm}^{3}$ で同一であ る. 上室の中心軸上端には自動車エンジン用の点火プ ラグを取付け, 混合気体を点火した. 下室には混合気 体および既燃気体の吸排気孔が設けられている. 上室 と下室の右側面にはひずみゲージ式圧力変換器 (NEC 三栄, 9E02-P5, 固有振動数 $71 \mathrm{kHz}$ ) を燃焼室内壁に 


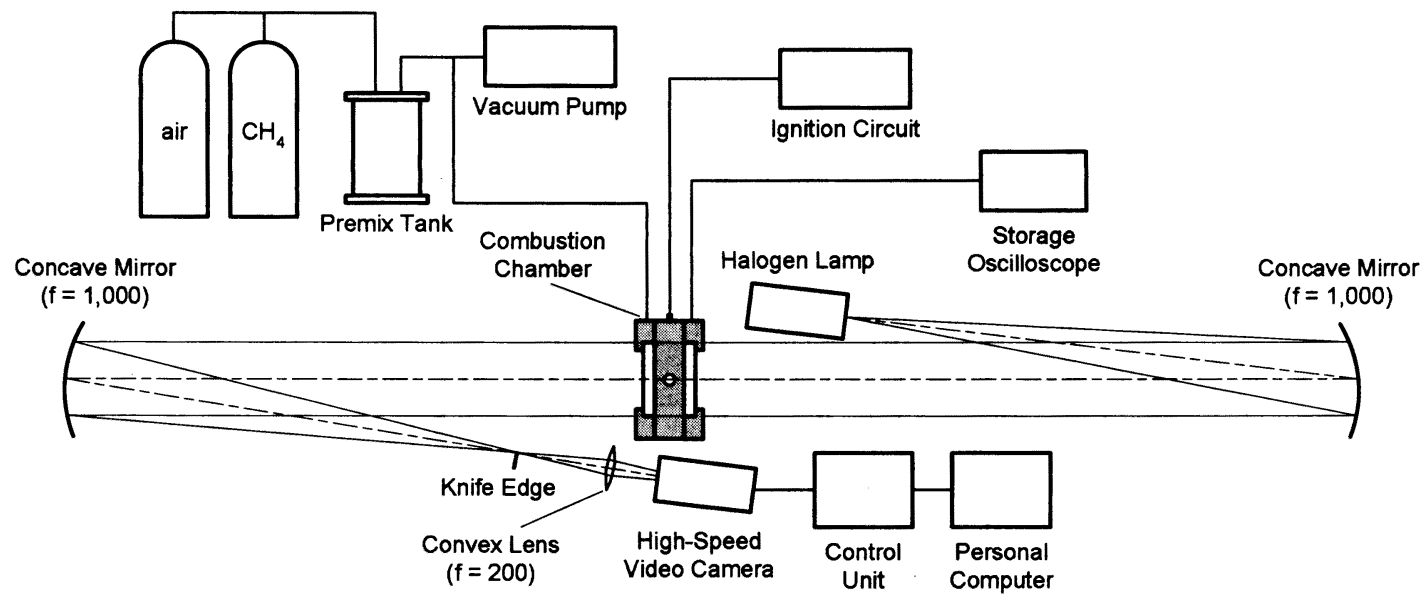

Fig. 2 Schematic diagram of experimental set-up with schlieren optics.

Table 1 Experimental conditions of test gas.

\begin{tabular}{ll}
\hline \multicolumn{1}{c}{ Parameter } & Conditions \\
\hline Gaseous Mixture & $\mathrm{CH}_{4}+$ air \\
Equivalence Ratio, $\phi$ & $0.8,1.0,1.2$ \\
Initial Pressure, $p_{0}[\mathrm{kPa}]$ & $30 \sim 101$ \\
Chamber Volume $\left[10^{5} \mathrm{~mm}^{3}\right]$ & 1.96 \\
Temperature & $293 \pm 5 \mathrm{~K}$ \\
\hline
\end{tabular}

対して面一に取付けた. これら圧力変換器をそれぞれ P1, P2 と呼ぶ.

図 2 に実験装置全体の概略を示す．当量比から求め られる分圧にしたがってメタンと空気をそれぞれ予混 合タンクに充填し, 約 12 時間程度拡散させてから実 験に用いた．火炎が間隙を伝ぱする挙動の観察には， ハロゲンランプ (モリテックス, MHF-G150LR)を光 源とするシュリーレン光学系および高速度ビデオカメ ラ (フォトロン, FASTCAM-MAX 120KC, 最高撮影 速度 $\left.1.2 \times 10^{5} \mathrm{fps}\right)$ を用いた. 高速度ビデオカメラは, コマ間隔 $1 / 3000 \mathrm{~s}$, 解像度 $512 \times 512$ ピクセルに設 定し，映像を $8 \mathrm{~s}$ 間記録した後で燃焼過程の映像記録 部分を抽出した. 圧力変換器からの信号はストレージ オシロスコープ (横河電機, DL-1540, サンプリング $200 \mathrm{MS} / \mathrm{s}$ ) を用いて記録した.

2.2 実験方法 表 1 に供試気体の実験条件を示 す. 実験に用いた供試気体は, メタンー空気混合気体 である. 供試気体の当量比 $\phi$ は $0.8,1.0,1.2$ の 3 条件 とし, 初期圧力 $p_{0}$ を $30 \sim 101 \mathrm{kPa}$ の範囲で変化させ た. 間隙を構成するためのブロック容積を除いた燃焼 室全体の容積は, $1.96 \times 10^{5} \mathrm{~mm}^{3}$ である. なお, 実 験は室温状態 $(293 \pm 5 \mathrm{~K})$ で行った.
Table 2 Experimental conditions of channel.

\begin{tabular}{ll}
\hline \multicolumn{1}{c}{ Parameter } & \multicolumn{1}{c}{ Conditions } \\
\hline Distance, $d[\mathrm{~mm}]$ & $1.2,1.6,2.2$ \\
Length, $L[\mathrm{~mm}]$ & 30 \\
Width, $w[\mathrm{~mm}]$ & 40 \\
Volume $\left[10^{3} \mathrm{~mm}^{3}\right]$ & $1.44,1.92,2.64$ \\
\hline
\end{tabular}

表 2 に実験に用いた間隙の諸量を示す. 間隙幅 $d$ を $1.2 \mathrm{~mm}, 1.6 \mathrm{~mm}, 2.2 \mathrm{~mm}$ の 3 条件で変化させた. 間隙 の長さを $L=30 \mathrm{~mm}$, 奥行を $w=40 \mathrm{~mm}$ で一定とし たため, 間隙部分の体積はそれぞれ, $1.44 \times 10^{3} \mathrm{~mm}^{3}$, $1.92 \times 10^{3} \mathrm{~mm}^{3}, 2.64 \times 10^{3} \mathrm{~mm}^{3}$ に相当する.

実験手順は次の通りである. まず, 燃焼室内に真ちゅ う製ブロックを取付け, 間隙幅 $d$ を設定する. 次に, 真空ポンプを用いて燃焼室内を一度真空にした後, 設 定圧力まで予め作成しておいた予混合気体を充填する. オシロスコープおよび高速度ビデオカメラをトリガ待 ちの状態にした後, 点火回路装置を用いて混合気体を 点火させた. なお, 高速度ビデオカメラの撮影時間は $8 \mathrm{~s}$ 間と長いため, 燃焼終了後に手動でトリガスイッ チを押し, トリガ信号入力前後のビデオ映像を記録す るセンタートリガ方式を用いた. 燃焼終了後は, 既燃 気体を速やかに燃焼室から排気させた.

\section{3. 実 結 果}

まず, 火炎が間隙内を伝ぱする場合と間隙内で消炎 する場合の挙動について可視化観察を行った結果を中 心に述べる. 次に, 供試気体の当量比 $\phi$, 初期圧力 $p_{0}$, 間隙幅 $d$ を変化させ, 火炎の伝ぱ・消炎現象に及ぼす 影響について述べる. 


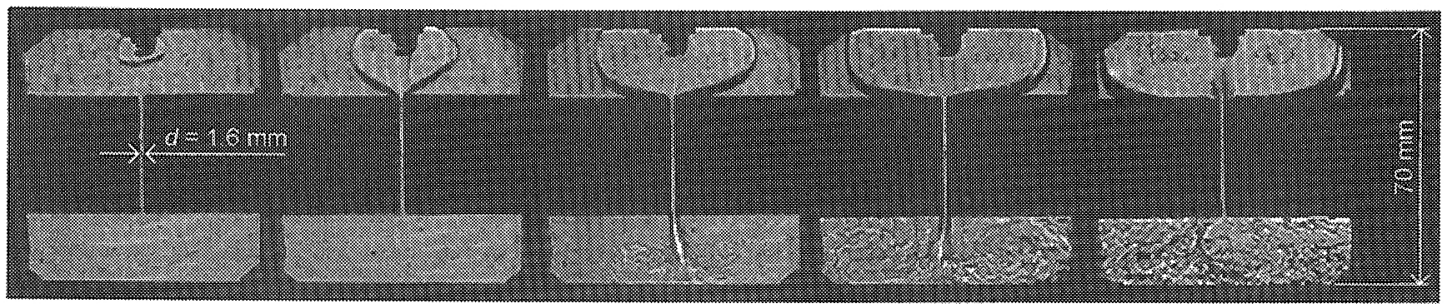

(a) $t=4 \mathrm{~ms}$

(b) $t=8 \mathrm{~ms}$

(c) $t=12 \mathrm{~ms}$

(d) $t=16 \mathrm{~ms}$

(e) $t=20 \mathrm{~ms}$

Fig. 3 Sequential schlieren photographs showing propagation processes of combustion wave through narrow channel, $t$ : elapsed time from ignition $\left(\phi=1.0, p_{0}=100 \mathrm{kPa}, d=1.6 \mathrm{~mm}\right)$.

3.1 間隙を伝ぱする場合図 3 は, 供試気体の 当量比 $\phi=1.0$, 初期圧力 $p_{0}=100 \mathrm{kPa}$, 間隙幅 $d=1.6 \mathrm{~mm}$ の条件に対して得られた結果であり, 火 炎が間隙を伝ぱした際に得られた時系列のシュリーレ ン写真である. 写真のコマ間隔は $4 \mathrm{~ms}$ であり, 点火 からの経過時間 $t$ をそれぞれの写真下部に示す. 各コ マの上部中心軸上に撮影される黒い影が点火電極であ る. 図 $3(\mathrm{a})$ は点火から $t=4 \mathrm{~ms}$ 経過した際の火炎 を示す. 点火電極の影響により楕円形の火炎が形成さ れており，下方に向かって伝ぱする様子が解る. 上室 においては, 既燃気体の膨張により末燃気体が圧縮さ れるため, 圧力波が火炎に先行して伝ぱすると考学ら れるが，この圧力波は弱く画像から判断することは難 しい. 図3(b)では, 火炎が間隙に近づくにつれて変 形し, 中心軸上の伝ぱ方向に対して凸の形状になる. また，火炎は間隙に吸込まれるようにして進入する。 火炎が伝ぱする現象は, 波面静止座標系で考えるなら ば火炎面に対して末燃気体が流入することに等価であ る. 火炎面が壁面に近づくと, 火炎面と壁面に挟まれ た末燃気体は壁面によってその運動が拘束され火炎面 に対して加速できないのに対し, 間隙上の未燃気体は 壁面の拘束がないことから火炎面に対して加速し流入 することができる.したがって，火炎形状は図 3(c) 以 降に示されるように時間経過とともに球形から大きく 逸脱し棈円形に変形する.また，燃焼開始とともに火 炎前方に未燃気体の流れが誘起され, 間隙内へ加速し 流大するので火炎も加速しながら間隙内へ進入する. 図 3(c) 以降で火炎が下室内へと伝ぱする様子が解る. 火炎が間隙から下室へ伝ぱする段階で発生する渦によ り，図3(d)に括いて火炎はドーナツ状に拡がり，ほ ぼ下室全体に伝ぱする．図 3(e) では下室で燃焼が終 了しており, その際の既燃気体が間隙を逆流し上室に 噴射される様子が観察できる.この時刻においても上 室では燃焼が終了していない，さらに，下室における 火炎面上には乱れが多く観察され，上室における滑ら

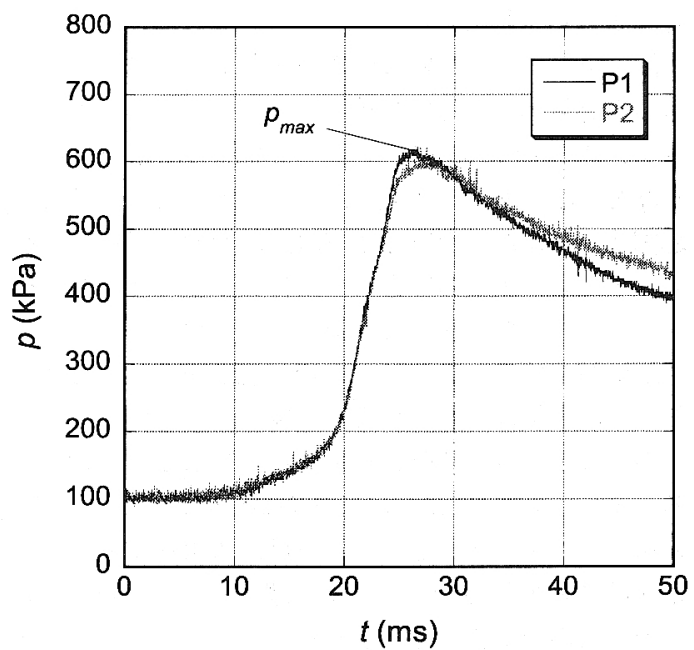

Fig. 4 Pressure histories simultaneously recorded with Fig. $3\left(\phi=1.0, p_{0}=100 \mathrm{kPa}, d=\right.$ $1.6 \mathrm{~mm})$.

かな火炎面とは異なる様相を呈する．下室における燃 焼時間は著しく短く, ビデオ映像を直接解析すれば火 炎が間隙から流出してから約 $8 \mathrm{~ms}$ で下室全体に拡が ることが解り, 上室における燃焼時間 $\tau \simeq 26 \mathrm{~ms}$ に比 較し著しく短い.

図 4 は, 図3に示したシュリーレン写真と同時計測 された圧力波形であり, 上室 $\mathrm{P} 1$ および下室 $\mathrm{P} 2$ にお ける圧力の時間変化を示す，上下の燃焼室における圧 力波形は，ほぼ同様の傾向を示し急峻に上昇する. 燃 焼過程において到達する最高圧力は $p_{\max } \simeq 600 \mathrm{kPa}$ であり, 初期圧力の約 6 倍に相当する. 点火から最高 圧力に到達するまでの時間は, $\tau \simeq 26 \mathrm{~ms}$ と見積もら れる. 図 3 に示したシュリーレン写真では, 点火から $t=20 \mathrm{~ms}$ 程度で火炎が下室のほぼ全体に燃え拡がる

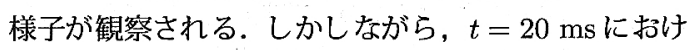
る圧力值は $200 \mathrm{kPa}$ 程度であり, それ以降に扔いて圧 


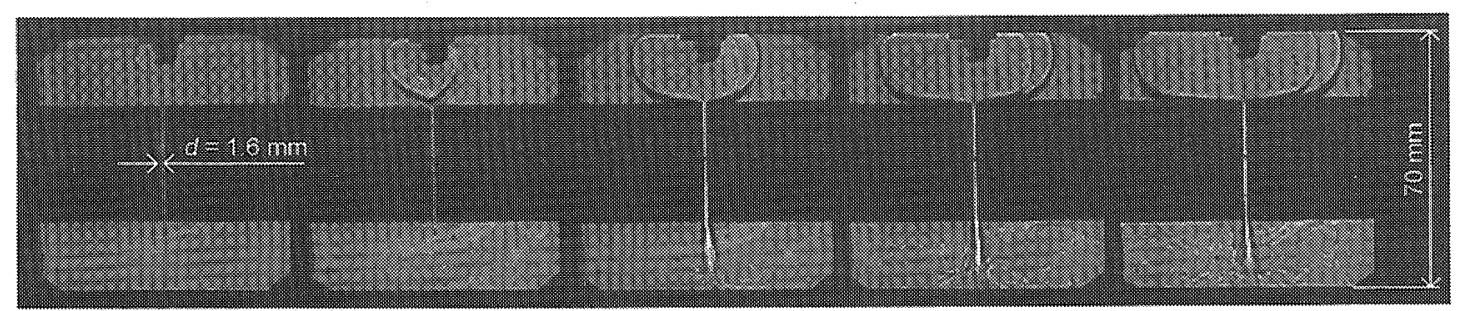

(a) $t=4 \mathrm{~ms}$

(b) $t=8 \mathrm{~ms}$

(c) $t=12 \mathrm{~ms}$

(d) $t=16 \mathrm{~ms}$

(e) $t=20 \mathrm{~ms}$

Fig. 5 Sequential schlieren photographs showing propagation processes of combustion wave through narrow channel, $t$ : elapsed time from ignition $\left(\phi=1.0, p_{0}=60 \mathrm{kPa}, d=1.6 \mathrm{~mm}\right)$.

力は $600 \mathrm{kPa}$ 程度にまで上昇する．これは，下室内の 予混合気が燃焼した際の既燃気体が間隙を逆流し, 上 室の未燃気体を急速に燃焼させることによると考えら れる. 図 3(e)において上室の間隙部分に観察される 密度変化は下室の既燃気体が上室に噴射されることに 起因する，また，上室と下室は間隙を介して接続され ているため, 上室の圧力上昇に伴い下室の圧力も上昇 する. 圧力は最高圧力に到達後, 時間経過とともに緩 やかに減少する．これは，火炎が燃焼室全体に伝ぱし た後, 既燃気体の熱量が燃焼室壁面および間隙を構成 するブロックへと移動し熱損失が生じることに起因す る. また, 上室 P1 における圧力減少の速度は下室 P2 のものよりも若干大きい，これは，火炎が上室全体へ と伝ぱする時間は下室におるるる燃焼時間よりも長く, この間に燃焼によって生じた熱量が燃焼容器壁面へ移 動し熱損失量が増えるためと考えられる.

\section{2 間隙内で消炎する場合図 5 は, 供試気体} の初期圧力を $p_{0}=60 \mathrm{kPa}$ にした場合のシュリーレン 写真であり, 当量比および間隙幅は図 3 と同様である. 図 5(a)では, 点火電極の影響により火炎形状は球形か ら逸脱している. 図 5(b)では, 間隙上部に打ける火炎 が伝ぱ方向に凸形状に変形している. 図 5(c) 以降で火 炎は間隙内に進入しており, 下室へと燃え拡がる様子 が解る. しかし, 図3に示した初期圧力 $p_{0}=100 \mathrm{kPa}$ のシュリーレン写真と比較すると, 下室内における燃 焼状態は活発ではなく, 後述する圧力波形の結果も考 慮するならば，この場合には火炎は間隙内において消 炎したと考元られる.すなおち，上室における既燃気 体が下室へと噴流として流入するのみであり，上室に おける火炎が下室へと伝ぱしていないと考えられる。

図 6 は, 図 5 に示したシュリーレン写真に同期し て得られた圧力波形である。上室および下室におけ る圧力の立上がりは緩慢であり, 到達する最高圧力も $p_{\text {max }}=150 \mathrm{kPa}$ 程度であり, 初期圧力の 2.5 倍程度で ある. また，点火から最高圧力に達するまでの時間も

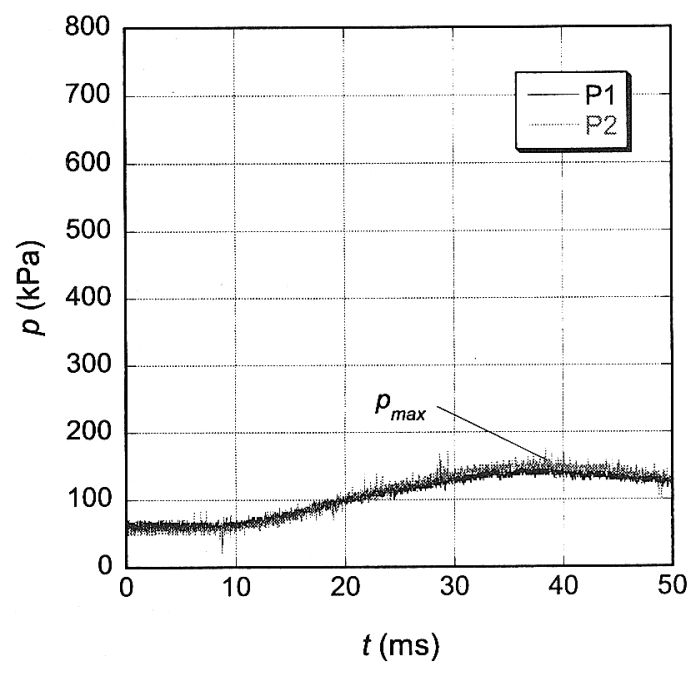

Fig. 6 Pressure histories simultaneously recorded with Fig. $5\left(\phi=1.0, p_{0}=60 \mathrm{kPa}, d=\right.$ $1.6 \mathrm{~mm})$.

$\tau \simeq 40 \mathrm{~ms}$ となり, 図 4 に示した $\tau \simeq 26 \mathrm{~ms}$ に比べて 長い. したがって, 供試気体の初期圧力を $p_{0}=60 \mathrm{kPa}$ に減じた条件では，上室における火炎は下室へと伝ぱ できず，間隙内において消炎したと考えられる．また， 上室に扔ける既然気体が下室内に流入することによっ て圧力上昇が生じるが, その際に到達する最高圧力は 初期圧力 $p_{0}=100 \mathrm{kPa}$ の場合に比較し著しく小さい ことが解る.

3.3 火炎の伝ぱ・消炎による差異図 7 は, 供 試気体の初期圧力 $p_{0}$ に対し燃焼過程において到達す る最高圧力 $p_{\text {max }}$ の関係を表す. 横軸は初期圧力 $p_{0}$, 縦軸は最高圧力 $p_{\text {max }}$ であり, 上室 (○印) と下室 ( $\square$ 印)における值をそれぞれ示す，この図より，燃焼過程 において到達する最高圧力には二つの異なる傾向があ る. 最高圧力 $p_{\text {max }}$ は, 初期圧力が $p_{0}=60 \sim 70 \mathrm{kPa}$ 


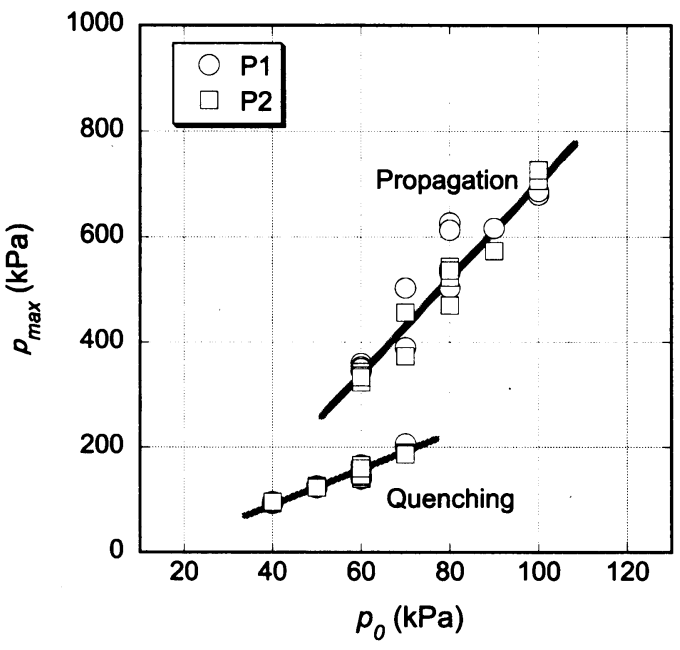

Fig. 7 Relationship between initial pressure $p_{0}$ and maximum pressure $p_{\max }$ obtained at upper and lower chamber $(\phi=1.0, d=1.6 \mathrm{~mm})$.

をしきい值とし，圧力が高い場合と低い場合の二つに 分類される. シュリーレン映像の結果も考虑するなら ば, 最高圧力が高い場合は火炎が間隙内で消炎するこ となく伝ぱした場合であり，最高圧力が低い場合は火 炎が間隙内で消炎した場合に分類される. 火炎が下室 に伝ぱした場合, 到達する最高圧力は初期圧力のおよ そ $6 \sim 7$ 倍であるのに対し, 消炎した場合には $2 \sim 3$ 倍程度である. 火炎が間隙内を伝ぱ・消炎したかに関 わらず，到達する最高圧力は初期圧力にほぼ比例する 結果が得られた. 初期圧力が $60 \leq p_{0} \leq 70 \mathrm{kPa}$ の条 件では，同条件で実験を行っているにも関わらず，火 炎が消炎する場合と伝ぱする場合の両方が観察された. これは, 混合気体を燃焼容器内に充填してからの時間 を一定にしていないため, 容器内における混合気体の 流動状態に差異があり，実験の再現性に影響を及ぼす ためと考えられる.

図 8 は, 間隙幅を $d=2.2 \mathrm{~mm}$ とした場合の同様 の結果である．燃焼過程において到達する最高圧力 が火炎の伝ぱと消炎で大きく異なる傾向については， 図 7 と同様である. しかし, 火炎が間隙内で消炎す る場合と伝ぱする場合の両方が観察される初期圧力が $p_{0} \simeq 40 \mathrm{kPa}$ に減少する.これは，間隙幅を $2.2 \mathrm{~mm}$ に増加したことにともない間隙部分の体積が増加し， 火炎背後における生成熱量も増加するため低い初期圧 力でも火炎は間隙を伝ぱすることができるためである.

図 9 は, 間隙幅を $d=1.2 \mathrm{~mm}$ とした場合の同様 の結果である. 火炎が間隙内を伝ぱする場合と消炎す

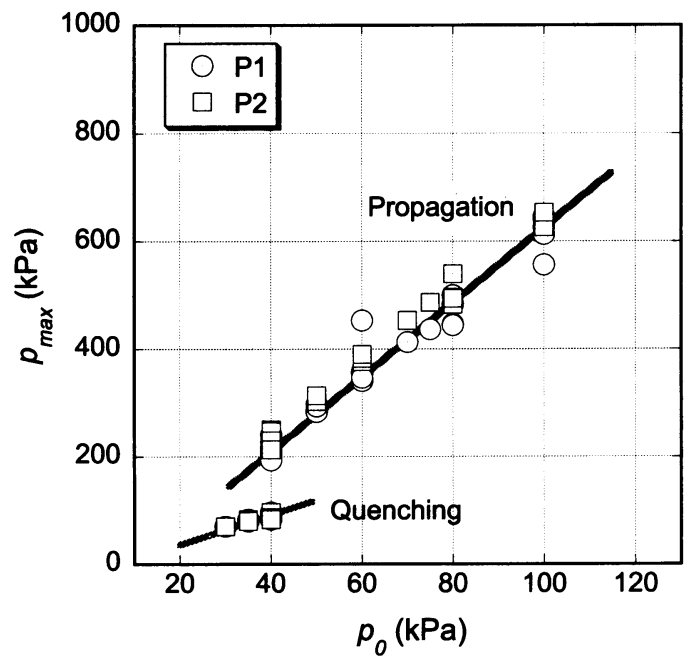

Fig. 8 Relationship between initial pressure $p_{0}$ and maximum pressure $p_{\max }$ obtained at upper and lower chamber $(\phi=1.0, d=2.2 \mathrm{~mm})$.

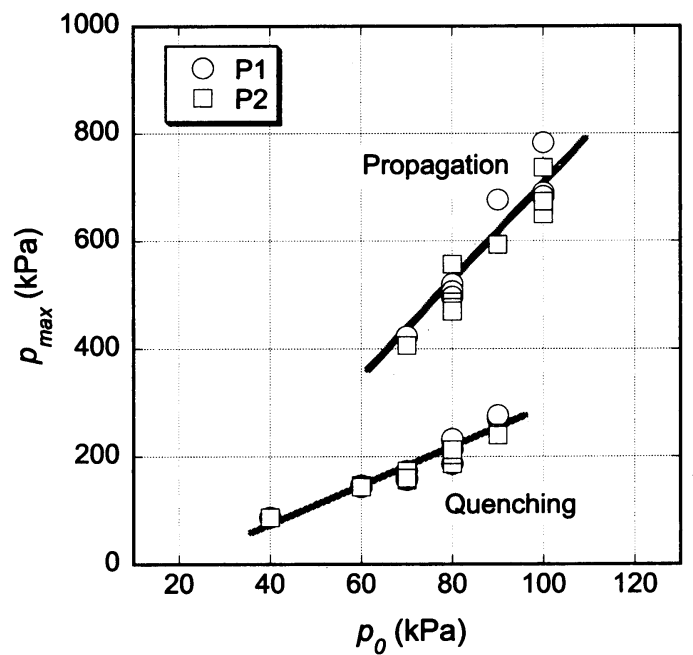

Fig. 9 Relationship between initial pressure $p_{0}$ and maximum pressure $p_{\max }$ obtained at upper and lower chamber $(\phi=1.0, d=1.2 \mathrm{~mm})$.

る場合の両方が観察される初期圧力は増加し, $p_{0}=$ $70 \sim 90 \mathrm{kPa}$ になる. これは, 間隙幅が $d=1.2 \mathrm{~mm}$ と小さいため, 火炎背後における生成熱量が小さく, 初期圧力を高くし生成熱量を増加させなければ，火炎 が伝ぱできないことを意味する.

図 10 は，燃焼室中心軸上における火炎先頭位置の 点火電極中心から鈶直下方への距離 $z$ と点火からの経 過時間 $t$ の関係を示し, 間隙幅を $d=2.2 \mathrm{~mm}$ (○印), 


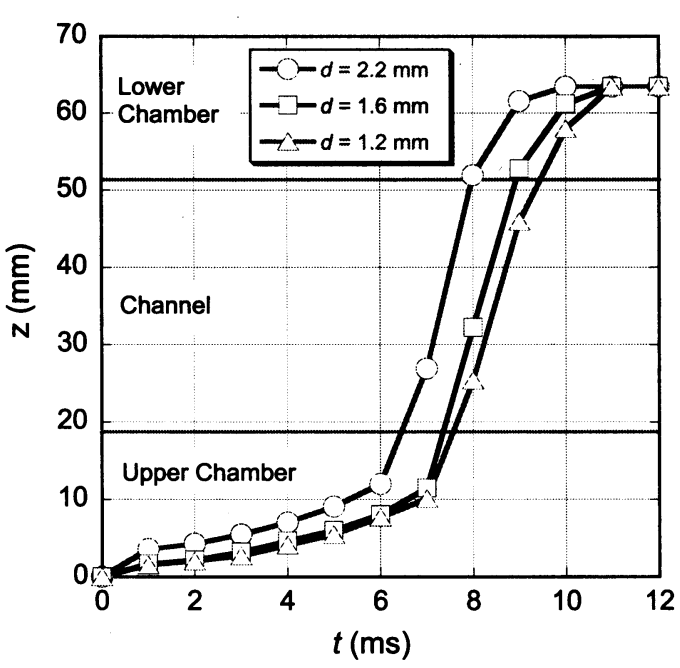

Fig. 10 Relationship between elapsed time from ignition $t$ and distance of combustion front from ignitor $z\left(\phi=1.0, p_{0}=100 \mathrm{kPa}\right)$.

$d=1.6 \mathrm{~mm}$ ( $\square$ 印), $d=1.2 \mathrm{~mm}\left(\triangle \mathrm{E}^{-}\right)$と変化させた 場合の結果を示す. 供試気体の当量比を $\phi=1.0$, 初 期圧力を $p_{0}=100 \mathrm{kPa}$ とした場合である. 点火電極 からの距離 $19 \leq z \leq 51 \mathrm{~mm}$ の区間が間隙内に相当 する. 上室における火炎の伝ぱ速度は小さく, 間隙幅 によって異るが $1.3 \sim 2.0 \mathrm{~m} / \mathrm{s}$ 程度である. 火炎が間 隙内に進入する直前から火炎の伝ぱ速度は著しく増加 する. これは，前述したように火炎前方に未燃気体の 流れが誘起され，間隙内へ加速し流入するもので火炎 も加速するためである. 間隙内における火炎伝ぱ速度 $V_{f}$ についても間隙幅によって異り, $d=1.2 \mathrm{~mm}$ の場 合, $V_{f}=32 \mathrm{~m} / \mathrm{s}, d=1.6 \mathrm{~mm}$ の場合, $V_{f}=27 \mathrm{~m} / \mathrm{s}$, $d=2.2 \mathrm{~mm}$ の場合, $V_{f}=20 \mathrm{~m} / \mathrm{s}$ と見積もられ, 間 隙幅が小さくなるにつれて火炎の伝ぱ速度は增加する. これは, 間隙幅が小さくなるほど火炎前方に誘起され る未燃気体の流れが間隙内で加速されるためである. 火炎が下室に進入すると前方の未燃気体により形成さ れた渦輪に沿って伝ぱするため, 中心軸上の移動速度 は低下する.

\section{4. 考察}

前述したように火炎が間隙を伝ぱする際, 火炎の伝 ぱを妨げる要因として, 間隙を構成する壁面への熱損 失および粘性の影響が挙げられる, また, 火炎の伝ぱ を促進する要因としては, 火炎前方に誘起される流れ， 定容然焼することによる圧力上昇が挙げられる.ここ

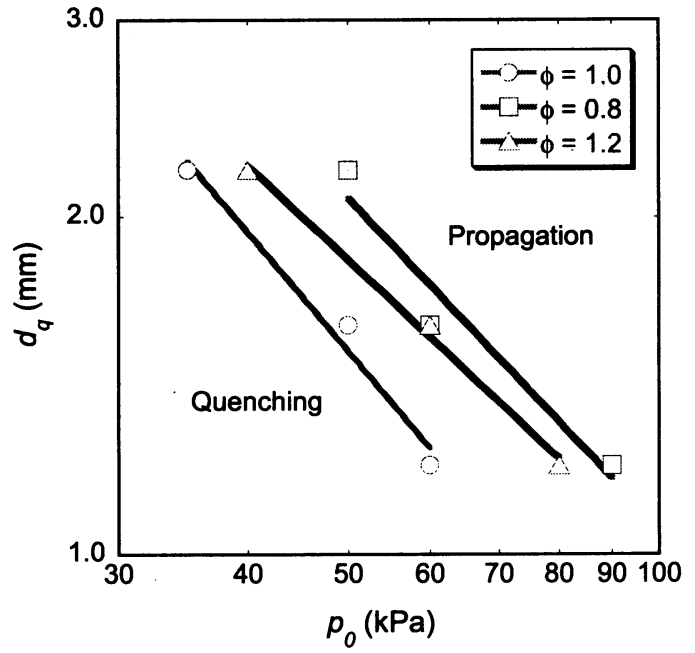

Fig. 11 Relationship between quenching distance of channel $d_{q}$ and initial pressure $p_{0}$ to distinguish propagation or quenching.

では, 火炎の消炎距離の圧力依存性について考察する.

一般に層流燃焼速度 $S_{L}$ の圧力依存性は反応次数を $n$ として次式で表される ${ }^{(4)}$.

$$
S_{L} \propto p^{n / 2-1}
$$

また, 消炎距離 $d_{q}$ は温度伝導率を $\alpha$ とすれば次式で 表される(4).

$$
d_{q} \propto \frac{\alpha}{S_{L}} \propto \frac{\alpha}{p^{n / 2-1}}
$$

温度伝導率 $\alpha$ は圧力 $p$ に逆比例することから, 消炎 距離 $d_{q}$ は次式で示すように圧力 $p$ の $n / 2$ 乗に反比例 する.

$$
d_{q} \propto p^{-n / 2}
$$

図 11 は, 供試気体の初期圧力 $p_{0}$ と消炎距離 $d_{q}$ の関 係を示し, 横軸は初期圧力 $p_{0}$ の対数, 縦軸は消炎距離 $d_{q}$ の対数であり, 当量比を $\phi=1.0$ (○印), $\phi=0.8$ ( $\square$ 印), $\phi=1.2$ ( $\triangle$ 印) と変化させた場合である. 間隙幅 が消炎距離 $d_{q}$ を示す実線よりも大きい場合には火炎 は間隙を伝ぱし，消炎距離よりも小さい場合には間隙 内で消炎したことを示す. 図 11 より,どの当量比に 対しても初期圧力を增加させることにより, 消炎距離 は隇少することが解る. 初期圧力 $p_{0}$ を大きくするほ ど, 間隙を伝ぱする火炎背後の既燃気体の体積が上昇 
して発生する熱量も増加するため, 間隙幅を小さくし なければ火炎が伝ぱすることが解る. また, 両対数グ ラフ上において消炎距離のデータは初期圧力に対して ほぼ直線上に分布することから，消炎距離 $d_{q}$ は初期 圧力 $p_{0}$ のべき関数で表され，この傾向は式 (3) と定性 的に一致する. 図 11 における傾きから反応次数を推 定するとほぼ $n \simeq 2$ であり, 燃焼速度から推定される 值とほぼ一致する. 供試気体の当量比を変化させた場 合, どの初期圧力に対しても断熱火炎温度の最も高い $\phi=1.0$ の場合に消炎距離が最も小さい. 量論のメタ ン-空気混合気の消炎距離は約 $2.1 \mathrm{~mm}$ と報告されて いることから ${ }^{(8)}$, 本実験によって得られた消炎距離は これよりも短い：これは，定容燃焼室で燃焼した場合 には既燃気体の膨張によって圧力波が火炎前方に形成 されて初期圧力が上昇することによると考えられる. さらに, 圧力波が火炎前方を伝ぱすることによって未 燃気体が乱され，消炎距離が短くなると考えられる.

\section{5. まとめ}

定容燃焼室の中央に間隙を設け，間隙上部において メタンー空気混合気体を点火した際に生成される火炎 が間隙に進入した際の挙動について, 供試気体の当量 比, 初期圧力, 間隙幅を変化させて実験を行った. 本 論において得られた結果を以下に要約する.

（1）火炎が狭い間隚に進入した際の挙動は，火炎が間 隙内で消炎せずに伝ぱする場合, 火炎が間隙内に おいて消炎し既燃気体が間隙から噴射される場合 の二種類に分類されることを明らかにした.

（2）火炎が間隙を伝ぱした場合には，上下の燃焼室に おいて圧力は急峻に立上がり, 初期圧力の $6 \sim 7$ 倍に達する. 一方, 火炎が間隙内で消炎した場合 には, 圧力の立上がりは緩慢であり最高圧力は初 期圧力の $2 \sim 3$ 倍程度となる. また, 火炎の伝ぱ・ 消炎に関わらず，到達する最高圧力は初期圧力に
ほぼ比例する.

（3）火炎が間隙を伝ぱするしきい值となる消炎距離は 初期圧力のべき関数で表される. 定容燃焼によっ て生じた火炎が間隙を伝ぱする場合にも, 消炎距 離が初期圧力のべき関数に比例することを明らか にした.

\section{謝 辞}

本実験を行うにあたり, 本学吉橋照夫 技師, 本学 大学院生 鈴木 文貴君および本学学部生 篠崎 勇気君 の協力を得た。.また, 高速度ビデオカメラを用いた火 炎の可視化観察には (株) フォトロン 古瀬雅人氏に協 カして頂いた.ここに付記し謝意を表する.

\section{文献}

(1) Niioka, T., et al., Fundamental of Combustion Phenomena, Ohmsha, (2001).

(2) Lee, S.T. and Tsai, C.H., Numerical investigation of steady laminar flame propagation in a circular tube, Combustion and Flame, 99 (1994), 484-490.

(3) Hackert, C.L., Ellzey, J.L. and Ezekoye, O.A., Effects of thermal boundary conditions on flame shape and quenching in ducts, Combustion and Flame, 112 (1998), 73-84.

(4) von Elbe, B.L.G., Combustion, flames and explosions of gases, $3 \mathrm{rd} \mathrm{Ed.,} \mathrm{Academic} \mathrm{Press,}$ (1987), 240-336.

(5) Ishizawa, S., et al., Estimation of flame quenching diameter by flush-back method, Proc. of the ThirtySeventh Japanese Symp. on Combustion, (1999), 427-428.

(6) JSME, JSME Combustion Handbook, JSME, (1995), 23-24.

(7) Bellenoue, M., et al., Direct measurement of laminar flame quenching distance in a closed vessel, Experimental Thermal and Fluid Science, 27 (2003), 323-331.

(8) Mihalik, T.A., et al., The flammability limits of gaseous mixtures in porous media, Proc. of $17 \mathrm{th}$ Int. Colloquium on the Dynamics of Explosion and Reactive Systems, (1999), (CD-ROM, No. 102). 